\title{
Humic acid based liquid organic fertilizer improved the growth of nursery and immature rubber plants grown in Boralu soil series
}

\author{
R S Dharmakeerthi*, J A S Chandrasiri* and V U Edirimanne* \\ * Rubber Research Institute of Sri Lanka, Dartonfield, Agalawatta, Sri Lanka
}

Received: 24 July 2013

\begin{abstract}
Humic substances, the major component of soil organic matter, play multiple roles that can greatly benefit plant growth through their indirect or direct effects. Effects of commercially available humic acid based liquid organic fertilizer, Humate Plus ${ }^{\circledR}$ $(H P)$, on growth and nutrient uptake of the rubber plants (Hevea brasiliensis $L$. Muell. Arg.) during nursery and immature stages were studied. Chemical fertilizers $(C F)$ were applied to rubber plants growing in Boralu soil series (Typic Paleudults) at 0 , and $100 \%$ of currently recommended rates. In another treatment $50 \%$ of $C F$ was supplemented with HP. Growth of the rubber plants were monitored periodically by measuring plant height, diameter or girth, and in nursery plants dry matter (DM) accumulation as well. Macro nutrient concentrations in the leaves, and different parts of the young budding plants, were determined to assess the nutritional status of the plant. Diameter of the nursery plants that received CF were not statistically different but DM accumulation in shoot was significantly higher, both at cut-back (17\%) and 12 weeks after cut-back (13\%) in 50\% CF +HP treatment compared to those in $100 \%$ $C F$ treatment. In field plants, girth at the end of $3^{\text {rd }}$ year was significantly higher (5 to $7 \%$ ) in $50 \% C F+H P$ treatment compared to that in $50 \%$ or $100 \%$ CF only treatments. Although there was no consistent trend on the effect of HP on leaf nutrient status in young budding plants, total $P$ and Ca uptake at the end of the nursery period was significantly higher in the 50\% CF+HP treatment. Results of this study suggest that humic acid based liquid organic fertilizers could be used to cut down the chemical fertilizer usage in rubber plantations while improving the growth of the rubber plants.
\end{abstract}

Key words: Hevea brasiliensi, humic acid, macro nutrients, organic fertilizer, young budding

\section{Introduction}

Organic matter plays a pivotal role in soil fertility. It provides substrates for soil microorganisms, enhance nutrient availability and improves moisture retention, among many other functions, 
through various direct and indirect interactions with soil properties and processes. However, during the last 100 years of rubber cultivation, organic $\mathrm{C}$ reserves in rubber growing soils have been depleted due to erosion of top soil and decomposition of soil organic matter. Organic $\mathrm{C}$ content in most of the rubber growing soils is around $0.5-1.0$ $\%$ at present (Kumaragamage, Nayakekorale \& Vidhana Arachchci. 1999). During this period soil nutrient reserves have also been depleted as a result of erosion of surface soils and crop removal. Degradation in soil fertility has negative impact on growth of the rubber plant and the productivity of the rubber lands in Sri Lanka.

Although soil chemical fertility is being managed at present using chemical fertilizers (Yogaratnam, Silva \& Weerasuriya, 1984; Dissanayaka \& Mitrasena, 1986), the fertilizer use efficiency in rubber plantations has found to be very low (Dharmakeerthi, 2010). This could be due to low cation exchange capacity, poor moisture retention or/and low microbial activity in rubber growing soils which are directly related to the soil organic matter content. Various organic residues and manures have been recommended for rubber plantations to improve soil fertility (Yogaratnam \& Silva, 1987; Anon, 2009). Their longevity in soils under hot and humid tropical condition is so short that repeated application in very large quantities is essential to maintain a relatively high fertility status. As a result adoption of this technology in rubber plantations is low. The use of humic acid is a promising natural resource to be utilized as an alternative for increasing soil fertility and crop production. It is a naturally occurring polymeric organic compound and is produced by the decay of organic materials and is found in soil, peat and lignites (Sharif, Khattak \& Sarir, 2002). Commercially, humic acid is extracted from organic matter in bog soils (Goff, 1982) or by fermentation of sea weeds (Campbell, 1993). It has the potential to improve cation exchange capacity, microbial activity and moisture retention in soils (Eyheraguibel, Silverstre \& Morard, 2008; Hanifa \& Salwa, 1998) and plant growth (Adani et al., 1998; Atieh et al., 2002). Bohme \& Thi Lua (1997) reported that humic acid had beneficial effects on nutrient uptake by plants, and was particularly important for the transport and availability of micronutrients. Hypotheses which account for the stimulatory effects of HA are numerous. The most convincing is a "direct action" on the plant, which is hormonal in nature. Zhang \& Ervin (2004) showed humic acid has cytokinin activity while Pizzeghello, Nocolini \& Nardi (2001) measured auxin-like and gibberellinlike activities, and a indole acetic acid (IAA) concentration. An "indirect action" on the metabolism of microorganisms and the dynamics of uptake of soil nutrients, substrate physical conditions through positive effects on seed germination, seedling 
growth, root growth, and shoot development has also been proposed (Cacco \& Dell'Agnolla, 1984; Chen \& Aviad, 1990; Piccolo, Nardi \& Concheri, 1991). Other hypothetical mechanisms include enhanced uptake of metabolic ions and increases in cell permeability (Chen and Aviad, 1990).

The decay of humic acid in soils is very slow (Qualls, 2004) compared to traditional organic residues. Any effect on soil fertility and plant growth is therefore expected to be long lasting. Requirement of humic acid in small quantities to achieve beneficial effects on plant growth is another advantage. However, no experiment has so far been conducted using humic acid containing organic fertilizers in rubber plantations in Sri Lanka. The objective of this study was to determine the effectiveness of a commercially available liquid organic fertilizer on the growth and nutrient uptake of rubber plants under nursery and field conditions.

\section{Methodology}

Two experiments, a nursery and a field experiment, were conducted in Boralu soil series (Typic Paleudults) at Paiyagala Estate, Dodangoda using a commercially available humic acid containing liquid organic fertilizer [Humate Plus ${ }^{\circledR}$ (HP) from Poly Chem Lanka (Pvt.) Ltd., 32/2 First Cross St., Pagoda, Nugegoda, Sri Lanka]. Rubber is predominantly grown in Boralu soil series in the Kalutara region of the Low Country Wet Zone and is a very infertile soil with poor organic matter content.
Therefore, we hypothesized that the benefits from HP, if any, could be clearly observed in these soils. The field experiment was initiated in May 2010 while the nursery experiment was started in July 2011.

Top soil $(0-30 \mathrm{~cm})$ was gravelly sandy clay loam in texture, contained $0.87 \%$ organic carbon, and the $\mathrm{pH}$ was 4.57 $(1: 2.5$, water). HP used in this experiment, on average, had $3.7 \%$ (w/w) ash, $0.83 \%$ Organic C, and a $\mathrm{pH}$ of 8.43 . Humic acid content was $2.23 \%$ $(\mathrm{w} / \mathrm{w})$.

\section{Field experiment}

Three hectare plot from a field in the New Division, Paiyagala Estate $\left(6^{\circ} 31^{\prime}\right.$ $56^{\prime \prime} \mathrm{N} ; 80^{\circ} 01^{\prime} 18^{\prime \prime} \mathrm{E}$ ) planted with the clone RRISL 2001 in May 2010 using poly-bagged young budding plants was demarcated for this experiment. Mucuna bracteata was established as a cover crop in June 2010 in between rubber plants as per the recommendations of the Rubber Research Institute of Sri Lanka (RRISL). There were five fertilizer treatments; 1) No fertilizer control, 2) $100 \%$ CF (RRISL recommended R/U/12:14:14 mixture + Dolomite), 3) $50 \% \mathrm{CF}$, 4) $50 \% \mathrm{CF}+$ $\mathrm{HP}$, and 5) HP only. HP was applied at $100 \mathrm{~mL}, 200 \mathrm{ml}$ and $400 \mathrm{ml}$ per plant per year in two applications for the first, second and third year after planting, respectively. Additional $15 \mathrm{~g}$ and $30 \mathrm{~g}$ of urea per plant per application were applied to all HP treated plots during the $1^{\text {st }}$ and $2^{\text {nd }}$ year, respectively. During the third year however, additional urea was 
not applied, because the leguminous cover crop had spread well in the experimental plots by that time. HP was diluted 20 times in water and spread around the base of the rubber plant. Treatments were replicated three times and arranged in a randomized complete block design.

Plant growth was monitored measuring height and diameter at planting, stem girth at $120 \mathrm{~cm}$ height thereafter. Girth increment during the year was then calculated by subtracting girth of a given year from girth of the previous year. Leaf samples were collected at the end of each year according to the method described by Yogaratnam (1984) and analyzed for macro (N, P, K, $\mathrm{Mg}, \mathrm{Ca}$ ) nutrient contents.

\section{Nursery experiment}

Plants were raised in black polyethylene bags filled with Boralu series soils collected from the top 0-30 cm layer of the nursery site at Paiyagala Estate $\left(6^{\circ}\right.$ $32^{\prime} 51^{\prime \prime} \mathrm{N}$; $80^{\circ} 00^{\prime} 53^{\prime \prime}$ E). Soils were sieved through a $1 \mathrm{~cm}$ mesh to remove large lateritic gravel and filled into gauge 300 polyethylene bags having lay-flat dimensions of $15 \mathrm{~cm}$ diameter and $37 \mathrm{~cm}$ height. At bag filling, 50g of high grade Eppawala rock phosphate were also added to each bag. After two weeks, a rubber seedling showing high vigor was transplanted in each bag. Fertilizer application started four weeks after transplanting and carried out at two-week intervals. There were three fertilizer treatments; 1) No fertilizer control, 2) $100 \% \quad \mathrm{CF} \quad$ (RRISL recommended R/YB/9:11:11:4 liquid formulation, and 3) $50 \% \mathrm{CF}+\mathrm{HP}$. Humate Plus ${ }^{\circledR}, 60 \mathrm{ml}$ before cut-back stage and $90 \mathrm{ml}$ after cut-back stage, was mixed thoroughly with the $4.5 \mathrm{~L}$ of liquid $\mathrm{CF}$ and applied into 90 plants. Each treatment had 4 replicates and each replicate consisted of 15 to 20 poly-bagged plants. Treatments were arranged in a randomized complete block design.

The nursery was managed as per the recommendations of the Rubber Research Institute of Sri Lanka (Tillekeratne \& Nugawela, 2001) for the production of clonal rubber plants. When the seedling plants (root stock) were 16 weeks old (grafting stage), base of their stems were grafted with a bud patches obtained from the clone RRIC 121. Four weeks thereafter, the successfully grafted seedling plants were pollarded (cut-back stage) leaving a $15-\mathrm{cm}$ snag above the bud patch and this facilitated the sprouting of the bud and growth of the desired clonel plant (scion).

Diameter at $2.5 \mathrm{~cm}$ above the ground level and height of the seedling plant and scion were measured at monthly intervals. Leaf samples were collected from the bottom most leaves of the matured top whorl at bud grafting stage and at the end of the nursery period for the determination of macro $(\mathrm{N}, \mathrm{P}, \mathrm{K}$, $\mathrm{Mg}$ and $\mathrm{Ca}$ ) nutrient contents. Above ground dry matter (DM) contents of the seedling plants at the cut-back stage and above and below ground DM contents of plants with scion at 12 weeks after 
R S Dharmakeerthi et al.

cut-back stage were measured. Leaves were separated from the rest of the above ground parts. Soil and dust particles adhered to the root system were carefully removed by washing them gently under running water and over a $0.5 \mathrm{~mm}$ sieve. Roots initiating from the tap root were collected separately. All decaying brown colored roots were considered as dead or near dead and were removed.

\section{Plant analysis}

Plant samples were dried at $70^{\circ} \mathrm{C}$ to a constant weight and the DM contents were recorded. Different plant parts were ground and digested in Conc. $\mathrm{H}_{2} \mathrm{SO}_{4} / 30 \% \quad \mathrm{H}_{2} \mathrm{O}_{2}$ (Wolf, 1982) to determine the nutrient concentrations $(\mathrm{N}, \mathrm{P}, \mathrm{K}, \mathrm{Mg}$ and $\mathrm{Ca}$ ) by SKALAR San++ auto analyser and GBC 9003 atomic absorption spectrophotometer. Total nutrient uptake by the plant was then calculated from the dry weights and nutrient concentrations in different plant parts.

\section{Statistical analysis}

Analysis of variance (ANOVA) was conducted using PROC GLM program of the SAS software package (SAS Institute Inc., 2004). ANOVA for growth parameters of the field plants were conducted using diameter of the plants at planting as a co-variate. Percentage data were arcsin transformed prior to analysis. Treatment means were separated using the Duncan's multiple range test or probability differences of the least square means when the covariate was significant.

\section{Results}

Performance of the nursery plants

Application of chemical fertilizers has significantly improved all growth parameters measured but shoot/root ratio, in the young budding plants (Table 1) compared to the no fertilizer control. A significant difference between the $100 \% \mathrm{CF}$ and $50 \% \mathrm{CF}+\mathrm{HP}$ treatments could be observed on some growth parameters, particularly on the dry matter accumulation. Also, differences between the two treatments were more evident on the growth after bud grafting and cut-back. Diameter and height of the seedling plant at bud grafting stage were not significantly different between the fertilizer added treatments whereas the two parameters in the scion were high $(8.7 \mathrm{~mm}$ and $71 \mathrm{~cm}$, respectively) in the $50 \% \mathrm{CF}+\mathrm{HP}$ added plants compared to plants in the $100 \% \mathrm{CF}$ treatment $(8.5 \mathrm{~mm}$ and $63 \mathrm{~cm}$, respectively). Dry matter accumulation in shoot was significantly higher, both at cut-back (17\%) and 12 weeks after cut-back (13\%), in the $50 \% \mathrm{CF}+\mathrm{HP}$ added treatment compared to the $100 \% \mathrm{CF}$ treatment. 
Table 1. Growth parameters measured at bud grafting, cut-back and end of the nursery period as affected by $C F$ and HP application

\begin{tabular}{|c|c|c|c|c|c|c|c|c|}
\hline \multirow{2}{*}{ 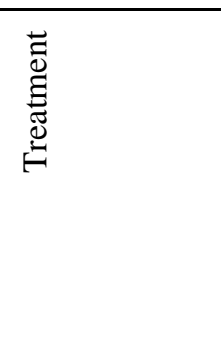 } & \multicolumn{3}{|c|}{$\begin{array}{l}\text { Seedling at } 14 \text { weeks after } \\
\text { planting }\end{array}$} & \multicolumn{5}{|c|}{$\begin{array}{c}\text { Stock and scion at } 12 \text { weeks after cut- } \\
\text { back }\end{array}$} \\
\hline & $\begin{array}{l}\text { Diameter } \\
(\mathrm{mm})\end{array}$ & 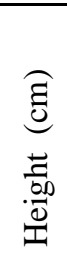 & 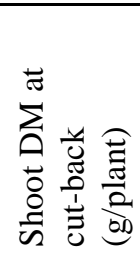 & 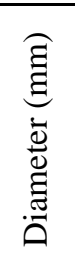 & 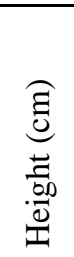 & 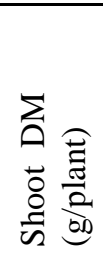 & 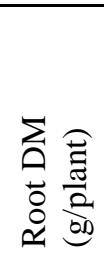 & 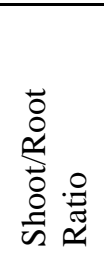 \\
\hline Control & $6.9^{b}$ & $68^{\mathrm{b}}$ & $12^{\mathrm{c}}$ & $6.8^{\mathrm{b}}$ & $44^{c}$ & $10^{\mathrm{c}}$ & $6^{b}$ & $1.56^{\mathrm{a}}$ \\
\hline $100 \% \mathrm{CF}$ & $8.9^{\mathrm{a}}$ & $90^{\mathrm{a}}$ & $24^{\mathrm{b}}$ & $8.5^{\mathrm{a}}$ & $63^{\mathrm{b}}$ & $19^{\mathrm{b}}$ & $11^{\mathrm{a}}$ & $1.73^{\mathrm{a}}$ \\
\hline $50 \% \mathrm{CF}+\mathrm{HP}$ & $9.0^{\mathrm{a}}$ & $90^{\mathrm{a}}$ & $28^{\mathrm{a}}$ & $8.7^{\mathrm{a}}$ & $71^{\mathrm{a}}$ & $21^{\mathrm{a}}$ & $13^{\mathrm{a}}$ & $1.63^{\mathrm{a}}$ \\
\hline
\end{tabular}

(Means with the same letter along the column is not significantly different at $5 \%$ probability level)

Mixed results were observed on some other important measurements made on nursery plants (Fig. 1). Because of the slow growth in no fertilizer added control treatment, percentages of graftable plants, i.e. plants with $>7 \mathrm{~mm}$ in diameter $(44 \%)$, and percentage of plants actually grafted (84\%) were significantly low. Grafted \% (100) was significantly higher in the $50 \% \mathrm{CF}+\mathrm{HP}$ treatment compared to $100 \% \mathrm{CF}$ treatment $(93 \%)$. Grafting success was around $95 \%$ in all three treatments but significantly higher $\%$ of plants $(94 \%)$ had been sprouted in the $50 \% \mathrm{CF}+\mathrm{HP}$ treatment compared to that of other two treatments. Die-back of the scion ranged from $1.5 \%$ to $4.3 \%$ among the three treatments, but the differences were not statistically significant.

Nutrient concentrations measured in the leaves collected at bud grafting stage and end of the nursery period are given in Table 2. Statistical significance among treatments varied depending on the type of the nutrient and growth stage. In both stages, leaf $P$ concentrations were not affected by the treatment but $\mathrm{CF}$ application increased the leaf K status. Application of $100 \%$ $\mathrm{CF}$ increased the leaf $\mathrm{N}$ levels significantly compared to the no fertilizer control but was not different from $50 \% \mathrm{CF}+\mathrm{HP}$ treatment. Leaf $\mathrm{Mg}$ and $\mathrm{Ca}$ status responded differently to treatments during the two growth stages.

6 
R S Dharmakeerthi et al.
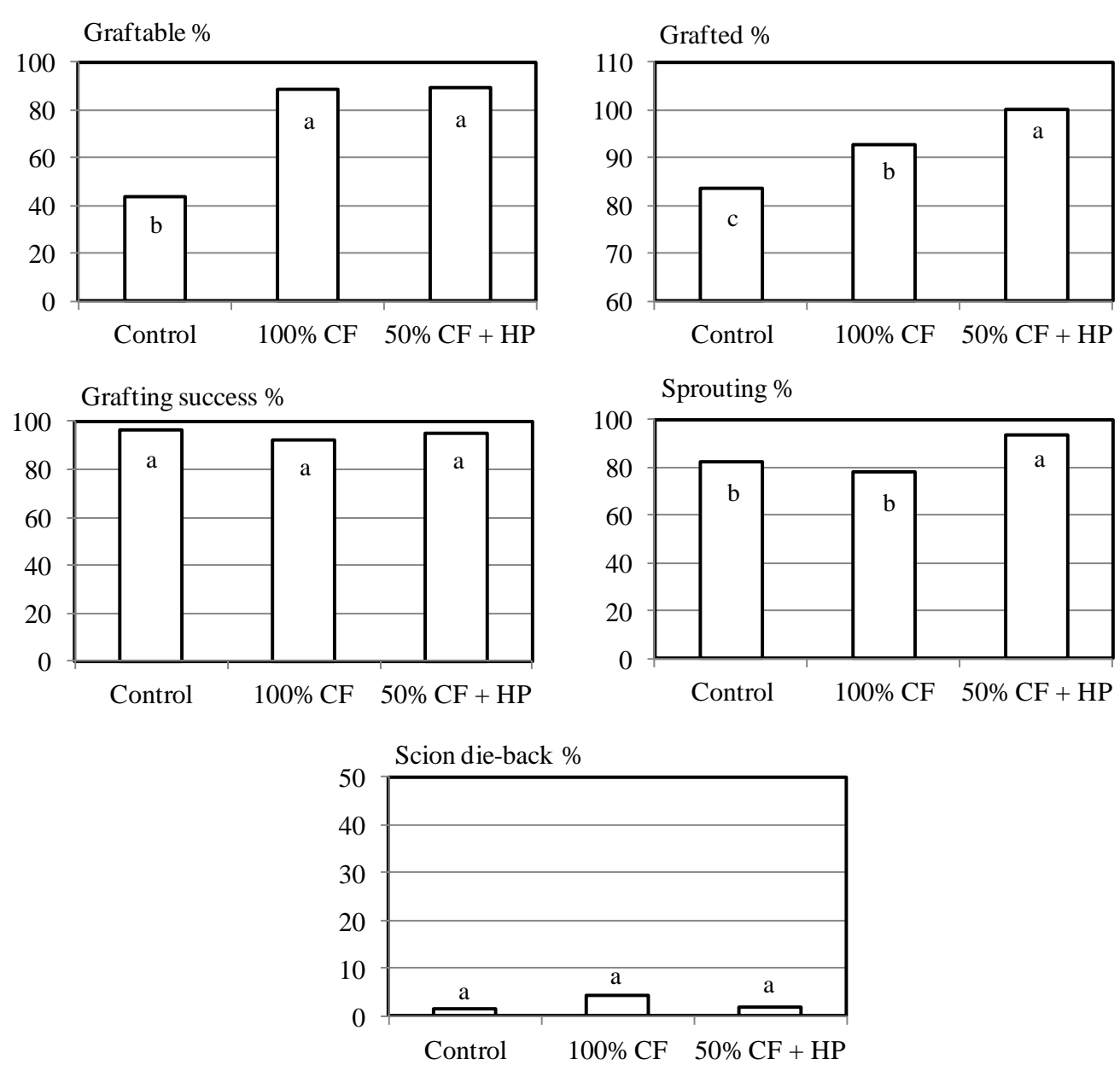

Fig. 1. Performance of young budding plants at and after bud-grafting as affected by $\mathrm{CF}$ and HP application. Bars with the same letter are not significantly different at $5 \%$ probability level

Total nutrient uptake by a plant at the end of the nursery period was determined using nutrient concentration and DM content data gathered for different plant parts. Uptake of all nutrients under investigation but $\mathrm{P}$ was significantly higher in the CF applied plants (Table 3). Total $\mathrm{P}$ uptake in the no fertilizer control and $100 \% \mathrm{CF}$ added treatments were the same $(42 \mathrm{mg} /$ plant $)$. From the $\mathrm{CF}$ applied plants, total $\mathrm{P}$ and $\mathrm{Ca}$ uptake were significantly higher in the HP added treatments $(64 \mathrm{mg} \mathrm{P} /$ plant and $66 \mathrm{mg} \mathrm{Ca} /$ plant) than those in the $100 \% \mathrm{CF}$ treatment (42 mg P/plant and $42 \mathrm{mg} \mathrm{Ca} /$ plant). 
Effect of humic acid on rubber growth

Table 2. Leaf nutrient concentrations at bud grafting and end of the nursery period in the three treatments

\begin{tabular}{|c|c|c|c|c|c|c|c|c|c|c|}
\hline \multirow{2}{*}{$\begin{array}{l}\text { Treat- } \\
\text { ment }\end{array}$} & \multicolumn{5}{|c|}{14 weeks after planting } & \multicolumn{5}{|c|}{12 weeks after cut-back } \\
\hline & $\mathbf{N}$ & $\mathbf{P}$ & $\mathbf{K}$ & $\mathrm{Mg}$ & $\mathbf{C a}$ & $\mathbf{N}$ & $\mathbf{P}$ & $\mathbf{K}$ & Mg & $\mathbf{C a}$ \\
\hline & & & & & & & & & & \\
\hline Control & $3.08^{\mathrm{b}}$ & $0.24^{\mathrm{a}}$ & $0.48^{\mathrm{b}}$ & $0.15^{\mathrm{b}}$ & $0.17^{\mathrm{b}}$ & $3.03^{\mathrm{b}}$ & $0.23^{\mathrm{a}}$ & $0.43^{\mathrm{b}}$ & $0.24^{\mathrm{a}}$ & $0.31^{\mathrm{a}}$ \\
\hline $100 \% \mathrm{CF}$ & $3.51^{\mathrm{a}}$ & $0.23^{\mathrm{a}}$ & $0.65^{\mathrm{a}}$ & $0.20^{\mathrm{a}}$ & $0.20^{\mathrm{ab}}$ & $3.64^{\mathrm{a}}$ & $0.20^{\mathrm{a}}$ & $0.82^{\mathrm{a}}$ & $0.21^{\mathrm{b}}$ & $0.24^{\mathrm{a}}$ \\
\hline $\mathrm{CF}+\mathrm{HP}$ & $3.37^{\mathrm{ab}}$ & $0.22^{\mathrm{a}}$ & $0.68^{\mathrm{a}}$ & $0.17^{\mathrm{ab}}$ & $0.22^{\mathrm{a}}$ & $3.30^{\mathrm{ab}}$ & $0.23^{\mathrm{a}}$ & $0.73^{\mathrm{a}}$ & $0.17^{\mathrm{c}}$ & $0.26^{\mathrm{a}}$ \\
\hline
\end{tabular}

(Means with the same letter along the column is not significantly different at $5 \%$ probability level)

Table 3. Total nutrient uptake at the end of nursery period as affected by the CF and HP application

\begin{tabular}{llllll}
\hline Treatment & $\mathbf{N}$ & $\mathbf{P}$ & $\mathbf{K}$ & $\mathbf{M g}$ & $\mathbf{C a}$ \\
\cline { 2 - 6 } & \multicolumn{5}{c}{$\mathbf{m g} / \mathbf{p l a n t}$} \\
\hline Control & $352^{\mathrm{b}}$ & $42^{\mathrm{b}}$ & $66^{\mathrm{b}}$ & $22^{\mathrm{b}}$ & $38^{\mathrm{b}}$ \\
$100 \% \mathrm{CF}$ & $528^{\mathrm{a}}$ & $42^{\mathrm{b}}$ & $203^{\mathrm{a}}$ & $30^{\mathrm{a}}$ & $42^{\mathrm{b}}$ \\
$50 \% \mathrm{CF}+\mathrm{HP}$ & $656^{\mathrm{a}}$ & $64^{\mathrm{a}}$ & $246^{\mathrm{a}}$ & $35^{\mathrm{a}}$ & $66^{\mathrm{a}}$ \\
\hline
\end{tabular}

(Means with the same letter along the column is not significantly different at $5 \%$ probability level)

\section{Performance of the field plants}

When compared to the no fertilizer control, the growth of the field plants treated only with HP has been significantly low throughout the 3-year experimental period (Table 4). Application of HP with 50\% CF was more effective on improving growth of the field plants than either $50 \%$ or $100 \%$ $\mathrm{CF}$ only treatments, particularly towards the latter part of the experiment. The mean girth of the plants by the end of the $3^{\text {rd }}$ year in $50 \% \mathrm{CF}+\mathrm{HP}$ treatment was $27.7 \mathrm{~cm}$ whereas it was $26.8 \mathrm{~cm}$ in the $100 \% \mathrm{CF}$ and $26.9 \mathrm{~cm}$ in $50 \% \mathrm{CF}$ only treatment. The girth increment during the $2^{\text {nd }}$ year were similar in all three treatments but during the $3^{\text {rd }}$ year that in the $50 \% \mathrm{CF}+\mathrm{HP}$ was $13.0 \mathrm{~cm}$ which was significantly higher compared to $12.4 \mathrm{~cm}$ in the $50 \% \mathrm{CF}$ and 12.1 in $100 \% \mathrm{CF}$ treatments. 
Table 4. Girth of the field plants at 1,2 and 3 years after planting as affected by different fertilizer treatments

\begin{tabular}{llcc}
\hline Treatment & \multicolumn{3}{c}{ Girth at the end of each year $(\mathbf{c m})$} \\
\cline { 2 - 4 } & 1 year & 2 year & 3 year \\
\hline Control & $6.8^{\mathrm{c}}$ & $12.8^{\mathrm{b}}$ & $24.4^{\mathrm{c}}$ \\
HP only & $6.9^{\mathrm{c}}$ & $12.0^{\mathrm{c}}$ & $22.3^{\mathrm{d}}$ \\
$100 \% \mathrm{CF}$ & $8.0^{\mathrm{b}}$ & $14.7^{\mathrm{a}}$ & $26.8^{\mathrm{b}}$ \\
$50 \% \mathrm{CF}+\mathrm{HP}$ & $8.1^{\mathrm{a}}$ & $14.7^{\mathrm{a}}$ & $27.7^{\mathrm{a}}$ \\
$50 \% \mathrm{CF}$ & $7.9^{\mathrm{b}}$ & $14.5^{\mathrm{a}}$ & $26.9^{\mathrm{b}}$ \\
\hline
\end{tabular}

(Means with the same letter along the column is not significantly different at $5 \%$ probability level)

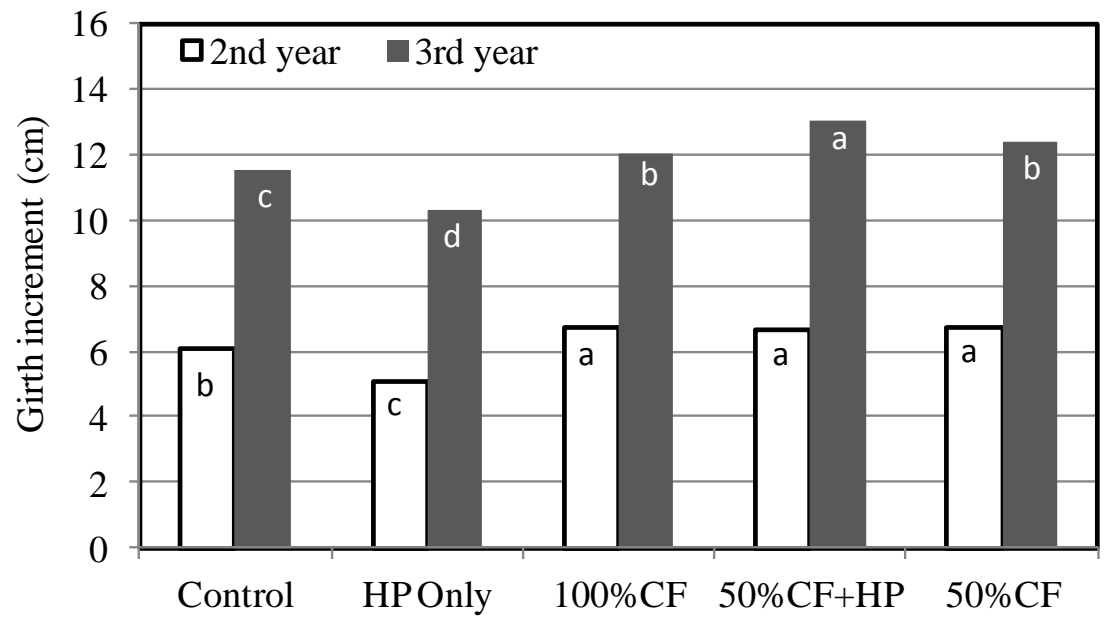

Fig. 2. Girth increment of the plants treated with CF and/or HP during the $2^{\text {nd }}$ and $3^{\text {rd }}$ year after planting. Bars within a series with the same letter are not significantly different at $5 \%$ probability level.

Nutritional status of the plants was assessed by measuring the leaf nutrient concentrations at the end of each year. Mean values of the nutrient concentrations obtained at the end of the $1^{\text {st }}$ and $2^{\text {nd }}$ year are given in Table 5 . Leaf $\mathrm{P}$ and $\mathrm{Mg}$ status were not significantly affected by different treatments. Also nutrient status among
$\mathrm{CF}$ added treatments were not significantly different. The highest $\mathrm{K}$ content $(0.62 \%)$ was observed in the $50 \% \mathrm{CF}+\mathrm{HP}$ treatment and it was significantly higher than those observed for $\mathrm{CF}$ not applied treatments. Leaf $\mathrm{Ca}$ contents were significantly low in the $50 \% \mathrm{CF}+\mathrm{HP}$ treated plants $(0.25 \%)$ compared to $\mathrm{CF}$ not applied treatments. 
Effect of humic acid on rubber growth

Table 5. Leaf nutrient status of the immature field plants averaged over the first two years after planting

\begin{tabular}{llllll}
\hline Treatment & $\mathbf{N}$ & $\mathbf{P}$ & $\mathbf{K}$ & $\mathbf{M g}$ & $\mathbf{C a}$ \\
\cline { 2 - 6 } & & \multicolumn{5}{c}{$\%$} & \\
\hline Control & $2.72^{\mathrm{b}}$ & $0.15^{\mathrm{a}}$ & $0.51^{\mathrm{c}}$ & $0.22^{\mathrm{a}}$ & $0.33^{\mathrm{a}}$ \\
HP only & $2.80^{\mathrm{b}}$ & $0.14^{\mathrm{a}}$ & $0.40^{\mathrm{d}}$ & $0.22^{\mathrm{a}}$ & $0.32^{\mathrm{a}}$ \\
$100 \% \mathrm{CF}$ & $2.89^{\mathrm{ab}}$ & $0.15^{\mathrm{a}}$ & $0.60^{\mathrm{ab}}$ & $0.22^{\mathrm{a}}$ & $0.29^{\mathrm{ab}}$ \\
$50 \% \mathrm{CF}+\mathrm{HP}$ & $3.01^{\mathrm{ab}}$ & $0.16^{\mathrm{a}}$ & $0.62^{\mathrm{a}}$ & $0.19^{\mathrm{a}}$ & $0.25^{\mathrm{b}}$ \\
$50 \% \mathrm{CF}$ & $3.18^{\mathrm{a}}$ & $0.15^{\mathrm{a}}$ & $0.57^{\mathrm{b}}$ & $0.20^{\mathrm{a}}$ & $0.29^{\mathrm{ab}}$ \\
\hline
\end{tabular}

(Means with the same letter along the column is not significantly different at $5 \%$ probability level)

\section{Discussion}

It is an accepted practice that in order to achieve high growth in rubber plants, irrespective of the nursery or immature period, application of $\mathrm{N}, \mathrm{P}, \mathrm{K}$ and/or $\mathrm{Mg}$ is mandatory under Sri Lankan conditions (Yogaratnam et al., 1984, Dissanayake \& Mitrasena 1986). This was confirmed again in this study too. Without chemical fertilizer application growth of the nursery as well as field plants had been retarded in this Boralu soil series. However, the use efficiency of applied fertilizer has been found to be around in 5 to $50 \%$, depending on the type of the nutrient, under Sri Lankan conditions (Dharmakeerthi, 2010) probably due in part to low CEC and high fixation in these soils. Application of Humic acid could increase the bioavailability of macro and micronutrients through complexation, chelation and/or improved nutrient exchange reactions (Chen \& Aviad, 1990; David, Nelson \& Sanders, 1994; Grossl \& Inskeep, 1991) and thereby increase the use efficiency.

Results from the nursery experiment confirmed that $50 \%$ cut-down in CF but supplemented with HP could produce plants that are comparable in diameter to currently recommended $100 \% \mathrm{CF}$ only practice. Dry matter accumulation in the tops however was significantly higher in HP applied treatment. One drawback of the treatment selection in the nursery experiment was the not inclusion of a $50 \% \mathrm{CF}$ only treatment. As a result the effect of HP alone could not be verified. In another experiment conducted using Agalawatta series soil, $50 \% \mathrm{CF}$ had produced plants with comparable growth to $100 \% \mathrm{CF}$ applied plants in young budding nurseries (Dharmakeerthi et al., 2010). In the field experiment however, 50\% CF only treatment was included. In that experiment, growth of the plants that received $50 \% \mathrm{CF}+\mathrm{HP}$ were significantly better than those in the $100 \%$ or $50 \% \mathrm{CF}$ treatments. This effect was more prominent during the period where the growth rate of the rubber plant was high. As a result, during the third year, plants in the $50 \% \mathrm{CF}+\mathrm{HP}$ treatment had achieved a $0.5 \mathrm{~cm}(3 \%)$ more girth than in the CF only treatments. 
R S Dharmakeerthi et al.

Improved growth of the $\mathrm{CF}$ applied treatments could be attributed to the improvement of $\mathrm{N}$ and $\mathrm{K}$ status in the leaves of the nursery and field plants. However, the higher growth in rubber plants in the $50 \% \mathrm{CF}+\mathrm{HP}$ treatment, could not be related to the nutritional status of the leaves (Table 2 and 5). This is contrary to observations made by others on annual crops. El-Nemr et al. (2012) observed that N, P, K, Ca and $\mathrm{Mg}$ concentrations in tomato leaves increased significantly when humic acid was used as a foliar application up to $3 \mathrm{~g} / \mathrm{L}$ in concentration. Nikbakht et al. (2008) observed in hydrophonic culture that macro and micronutrient contents of leaves including $\mathrm{N}, \mathrm{P}, \mathrm{K}, \mathrm{Ca}, \mathrm{Mg}, \mathrm{Fe}$, and $\mathrm{Zn}$ were significantly enhanced by humic acid when used at $1000 \mathrm{mg} / \mathrm{L}$. Several other studies have reported that humic acid have beneficial effects on total nutrient uptake by plants (Bohme \& Thi Lua 1997; Tattini et al., 1990; Adani et al., 1998). Although the leaf nutrient concentrations were not significantly different among CF added treatments, significantly high $\mathrm{P}$ and $\mathrm{Ca}$ uptake by the end of the nursery period was observed in 50\% CF-HP treated plants. Grossl \& Inskeep (1991) reported humic acid from wheat straw leachate can inhibit the formation of insoluble $\mathrm{Ca}$ phosphates and thus may enhance $\mathrm{P}$ and $\mathrm{Ca}$ bioavailability and uptake.

Improved growth in HP added plots could also be due to direct action of homone-like activities associated with humic acid. Several studies has revealed that humic acid has cytokinin activity, auxin-like and gibberellin-like activities as well as they contain indole acetic acid (Zhang \& Ervin, 2004; Pizzeghello et al., 2001). These hormones could stimulate root growth resulting enhanced surface area for absorption of nutrients and water. Although the total root dry matter content in $50 \% \mathrm{CP}+\mathrm{HP}$ treatment in the nursery plants was not significantly different from that in $100 \% \mathrm{CF}$ treatment (Table 1), we observed a significantly high feeder root biomass in the HP added treatment (data not shown). In addition, Chen \& Aviad (1990) hypothesize that mechanisms such as enhanced uptake of metabolic ions and increases in cell permeability could also be responsible for improved crop growth in humic acid treated plants. Low molecular size (LMS <3500 Da) fraction is the major candidate for determining the positive effects of humic substances on plant growth as they easily reaches the plasmalemma of higher plant cells and, in part, is taken up into them (Nardi et al., 2002).

Additional benefits of HP in young budding nurseries are the higher $\%$ of plants could be grafted and the sprouting of successfully grafted bud patch was faster and significantly higher. Therefore, number of plants that could be produced by the end of the nursery period was high.

Despite beneficial effects expected from humic substances on plant growth, application of HP at quantities used in the field experiment and without any $\mathrm{CF}$ 
had a significant negative effect on girthing of rubber plants during the first three years. This retardation was worse than that in no fertilizer applied plants. During the first two years 30 and $60 \mathrm{~g}$ of urea were applied to HP plots to negate any negative effect on plant growth that could result from immobilization of plant available $\mathrm{N}$ due to enhanced microbial growth after HP application. Application of urea had no significant effect on the leaf $\mathrm{N}$ concentration compared to that of the no fertilizer control. However, leaf $\mathrm{K}$ concentration in HP only treatment was significantly low. Application of high doses of $\mathrm{N}$ fertilizers could depress leaf $\mathrm{K}$ concentrations (Yogaratnam \& Mel, 1985) and as a consequent the growth of the immature plant could be retarded (Jessy et al., 2006). Therefore, an imbalance between $\mathrm{N}$ and $\mathrm{K}$ availability could have been the significantly low growth of the HP only treatment compared to that of no fertilizer control. Although the exact mode of action of HP on the growth of the rubber plants was not identified in this study, it is speculated that improvements in nutrient uptake, particularly $\mathrm{P}$ and $\mathrm{Ca}$, and/or stimulation of root growth through hormone-like actions of low molecular size humic acid could have been the reasons. This argument is corroborated, in part, from the results of the nursery experiment.

\section{Conclusions}

This study reconfirmed the need of chemical fertilizers to improve growth of rubber plants in Boralu soil series during the nursery and immature stages. However, $50 \%$ of the currently recommended chemical fertilizers provided a growth comparable to that in $100 \%$ chemical fertilizers during the immature period. Supplementing 50\% of chemical fertilizer with humic acid based liquid organic fertilizer, Humate Plus ${ }^{\circledR}$, improved the growth of the rubber plants more than those in chemical fertilizer alone treatments during the nursery stage as well as at the end of the $3^{\text {rd }}$ year of the immature period. Therefore, it appears that low soil fertility in this organic matter depleted Boralu soil series had been improved by application of humic acid containing organic fertilizers. In future experiments, different proportions of humic acid and chemical fertilizers in different soil types should be evaluated to identify the optimum combination to achieve the maximum growth. As the price of $\mathrm{CF}$ is expected to increase continuously in the future, our finding, that a part of $\mathrm{CF}$ used in rubber plantations could be replaced by locally available liquid organic fertilizers, could be a huge advantage to rubber growers in Sri Lanka and to the Government who spend nearly $1 \%$ of GDP on CF subsidy, at present.

\section{Acknowledgements}

Authors are thankful to the management of the Kotagala Plantations and Poly Chem Lanka Pvt. Ltd. for funding this study. Support extended by Mr. Shreenath Livera, Manager, Paiyagala 
R S Dharmakeerthi et al.

Estate and his Field Officers (especially Mr. Gayan and Mr. Pradeep) in maintaining experimental plots is gratefully acknowledged. Statistical analyses were conducted by Dr Wasana Wijesooriya, Biometrician of the Rubber Research Institute of Sri Lanka.

\section{References}

Adani, F, Genevini, P, Zaccheo, $\mathrm{P}$ and Zocchi, G (1998). The effect of commercial humic acid on tomato plant growth and mineral nutrition. Journal of Plant Nutrition 21(3), 561-575.

Anon (2009). Fertilizers for rubber. Advisory Circular. Rubber Research Institute of Sri Lanka.

Atiyeh, R M, Lee, S, Edwards, C A, Arancon, N Q and Metzger, J D (2002). The influence of humic acids derived from earthworm-processed organic wastes on plant growth. Bioresource Technology 84(1), 7-14.

Bohme, M and Thi Lua, H (1997). Influence of mineral and organic treatments in the rhizosphere on the growth of tomato plants. Acta Horticulturae 450,161-168.

Cacco, G and Dell'Agnola, G (1984). Plant growth regulator activity of soluble humic complex. Canadian Journal of Soil Science 62, 306-310.

Campbell, W E (1993). Plant growth product - US Patent 5,201,930.

Chen, Y and Aviad, T (1990). Effects of humic substances on plant growth. In: Humic Substances in Soils and Crop Science: Selected Readings, (MacCarthy, P, Clapp, C E, Malcom R L and Bloom P R eds.) Soil Science Society of America, Madison, pp 161-186.

David, P P, Nelson, P V and Sanders, D C (1994). A humic acid improves growth of tomato seedling in solution culture. Journal of Plant Nutrition 17(1), 173184.

Dissanayaka, D M A P and Mitrasena, U (1986). Influence of fertilizers on growth and mineral composition of Hevea seedlings grown in the field nursery. Journal of the Rubber Research Institute of Sri Lanka 65, 32-46.

Dharmakeerthi, R S (2010). Simple protocol for fertilizer recommendation to immature rubber with a simulation model based on ecophysiological parameters. Final Report of the NSF Research Grant No. RG/2005/AG/08.

El-Nemr, M A, El-Desuki, M, El-Bassiony, A M and Fawzy, Z F (2012). Response of growth and yield of cucumber plants (Cucumis sativus L.) to different foliar applications of humic acid and biostimulators. Australian Journal of Basic and Applied Sciences 6(3), 630-637.

Eyheraguibel, B, Silvestre, J and Morard, P (2008). Effects of humic substances derived from organic waste enhancement on the growth and mineral nutrition of maize. Bioresource Technology 99(10), 4206-4212.

Goff, D W (1982). Method of producing humic acid - US Patent 4,319,041.

Grossl, P R and Inskeep, W P (1991). Precipitation of dicalcium phosphate dihydrate in the presence of organic acids. Soil Science Society of American Journal 55, 670-675.

Hanafi, M M and Salwa, H (1998).Cadmium and zinc in acid tropical soils. II. Influence of humic acid addition on soil properties and their adsorption. Communications in Soil Science and Plant Analysis 29, 19331947. 
Isherwood, K F (1999). Fertilizer Use and the Environment. 5th AFA International annual conference Calgo, Egypt.

Jessy, M D, Nair, A N S, Joseph, P, Prathapan, K, Krishnakumar, V, Nair, R B, Mathew, $\mathrm{M}$ and Punnoose, $\mathrm{K} \mathrm{I}$ (2006). Response of the high yielding Hevea clones RRII 105 to fertilizers. Natural Rubber Research 19(1\&2), 3845.

Kumaragamage, D, Nayakekorale, H B and Vidhana Arachchi, L P (1999). Risks and limitations of wet zone soils. In: Soils of the Wet Zone of Sri Lanka. (Mapa, R B, Somasiri, S and Nagarajah, $\mathrm{S}$ eds.). Soils Science Society of Sri Lanka. pp 139-159.

Nardi, S, Pizzeghello, D, Muscolo, A and Vianello, A (2002). Physiological effects of humic substances on higher plants. Soil Biology and Biochemistry 34, 15271536.

Nikbakht, A, Kafi, M, Babalar, M, Xia, YP, Luo, A and Etemadi, N (2008). Effect of humic acid on plant growth, nutrient uptake, and postharvest life of Gerbera. Journal of Plant Nutrition 31, 21552167.

Piccolo, A, Nardi, S and Concheri, G (1991). Structural characteristics of humic Substances as related to nitrate uptake and growth regulation in plant systems. Soil Biology and Biochemistry 23, 833-836.

Pizzeghello, D, Nicolini, G, and Nardi, S (2001). Hormone-like activity of humic substances in Fagus sylvatica forests. New Phytologist 151, 647-657.

Qualls, R G (2004). Biodegradability of humic substances and other fractions of decomposing leaf litter. Soil Science Society of America Journal 68, 17051712.
SAS Institute Inc. (2004) SAS systems for Microsoft Windows. Release 9.1. SAS Institute, Inc, Cary, NC.

Sharif, M, Khattak, R A and Sarir, M S (2002). Effect of different levels of lignitic coal derived humic acid on growth ofmaize plants. Communication in Soil Science and Plant Analysis 33, 3567-3580.

Tattini, M, Chiarini, A, Tafani, R and Castagneto, M (1990). Effect of humic acids on growth and nitrogen uptake of container-grown olive (Olea europaea L. 'Maurino'). Proceedings of the International Symposium on Olive Growing, Wageningen (Netherlands). pp. 125-128.

Tillekeratne, L M K and Nugawela A (2001). Handbook of Rubber, Volume 1: Agronomy. Rubber Research Institute of Sri Lanka. Agalawatta, Sri Lanka.

Wolf, B (1982). A comprehensive system of leaf analyses and its use for diagnosing crop nutrient status. Communications in Soil Science and Plant Analysis 13, 1035-1059.

Yogaratnam, N (1984). Practical aspects of leaf sampling. In: A Practical Guide to Rubber Planting and Processing (Eds. A. de S. Liyanage and O. S. Peries). Rubber Research Institute of Sri Lanka. pp. 109-116.

Yogaratnam, N and De Mel, J G (1985). Effect of fertilizer on leaf composition of NPK in some Hevea cultivars. Journal of the Rubber Research Institute of Sri Lanka 63, 17-25.

Yogaratnam, N and Silva, F P W (1987). Use of organic materials as fertilizers. Bulletin of the Rubber Research Institute of Sri Lanka 24, 17-20.

Yogaratnam, N, Silva, F P W and Weerasuriya, S M (1984). Recent developments in the nutrition of Hevea 
in Sri Lanka. Proceedings of the International Rubber Conference Vol. 1 Part (1), September 17-19, Colombo, Sri Lanka. Rubber Research Institute of Sri Lanka. pp. 207 -247.

Zhang, X Z and Ervin, E H (2004). Cytokinin-containing seaweed and humic acid extracts associated with creeping bentgrass leaf cytokinins and drought resistance. Crop Science 5, 1737-1745.

Address for correspondence: Dr R.S. Dharmarkeerthi, Department of Soil Science, Faculty of Agriculture, University of Peradeniya, Peradeniya 20400, Sri Lanka. e-mail:dharmakeerthirs@gmail.com 